\title{
Carta para Ihe falar do meu bálsamo
}

\section{"A letter to tell you about what comforts me"}

Vânia Mattos da Silva ${ }^{1}$

Ao refletir sobre a forma de homenageá-lo, cheguei à conclusão de que isso poderia vir à tona através daquelas impressões que não se apagam. Assim (você não gostava deste meu 'assim'!) percebi que minhas imagens são tácitas e serão levadas comigo da mesma forma que você levou as suas. Porém, um misto de saudade e alegria me arrebata porque aquilo que hoje são lembranças um dia foram palavras pronunciadas e escritas para você; sentimentos de carinho, amizade e respeito que tive a oportunidade de demonstrar. Foi impossível enjaular o meu espírito e deixar que só a secretária sobressaísse. Ah, se eu pudesse imitar $\mathbf{O}$ Pequeno Príncipe ${ }^{2}$ com a sua rosa: colocá-lo em uma redoma e lhe defender das dores do mundo.

Oito anos de convívio ficaram impressos na minha mente e, quando tento revelar fatos do cotidiano, eles me parecem uma holografia ${ }^{3}$. Vejo parte de cenas que me remetem ao todo; entro em sua sala e já não sinto tristeza porque lá está a sua imagem; elegantemente sentado e ainda sorrindo. Ainda escuto sua voz, sempre tranquila, e ainda lhe percebo inteiro, porque você nunca foi metade de nada.

Nós, seus amigos, ficamos órfãos (escutei sua peculiar risadinha!) e, no meu ponto de vista, órfão é aquele que perde alguém in-subs-ti-tu-í-vel. Você não era a minha bengala, mas eu tinha um suporte; a sua presença me transportava para uma dimensão mais ampla, uma passagem do soturno para a exultação. Era a sua luz que fazia toda a diferença.

Hoje não tenho mais sua presença física, mas desfruto ainda da sua energia no meu ambiente, e isso me faz bem, mesmo sabendo que ela se dissipará com o tempo porque não se destina a muitos, mas aos seletos.

E, quando ela se for, tudo isso estará em mim; como tatuagem na alma “... para me dar coragem de seguir viagem"!

Texto submetido em 15 de fevereiro de 2012 e aceito para publicação em 15 de março de 2012.

${ }^{1}$ Graduada em Pedagogia pela Universidade Gama Filho; Pós-Graduada em Gestão de Recursos Humanos pela Fundação Getúlio Vargas/EBAPE; Assistente Administrativo da Direção da Escola Brasileira de Administração Pública e de Empresas; Atuou como Secretária Executiva do Cadernos EBAPE.BR durante a gestão do Professor Marcelo Milano. Endereço: FGV/EBAPE - Escola Brasileira de Administração Pública e de Empresas, Praia de Botafogo, 190 - $5^{\circ}$ andar, Botafogo, CEP 22250-900, Rio de Janeiro RJ, Brasil. E-mail: vania.silva@fgv.br

${ }^{2}$ Romance do escritor francês Antoine de Saint-Exupéry.

3 "Os hologramas possuem uma característica única: cada parte deles possui a informação do todo. Assim, um pequeno pedaço de um holograma terá informações de toda a imagem do mesmo holograma completo. (...) A comparação pode ser feita com uma janela: se a cobrirmos, deixando um pequeno buraco na cobertura, permitiremos a um espectador continuar a observar a paisagem do outro lado, de um ângulo muito restrito. Mas ele ainda verá toda a paisagem pelo buraco. (...)" Disponível em: http://pt.wikipedia.org/wiki/Holografia.

${ }^{4}$ Trecho adaptado da música Tatuagem, de Chico Buarque. 